\title{
Problems of Integrated Planning of Logistics Activities in the Supply Chain
}

\author{
L.A. Sosunova ${ }^{1}$, N.V. Astafieva ${ }^{2}, O . V$. Yudakova $^{1, *}$ and N.E. Petrova ${ }^{1}$ \\ *Corresponding author: olg-yudakova@yandex.ru \\ ${ }^{1}$ Samara State University of Economics, Samara, Russia. \\ ${ }^{2}$ Yuri Gagarin State Technical University of Saratov, Saratov, Russia.
}

\begin{abstract}
The processes of market integration and globalization are increasingly transforming enterprises into a network or structure of a macro-logical system or supply chain. The scale and scope of activities of such companies require their division into several groups - by functions, regions, divisions and so on. At the same time, each group is responsible for the management assigned to it by part of the business. Therefore, there is a need to use a comprehensive or integrated planning of logistics activities, which will not only see the future prospects, but also to show the entire chain of the business process of the organization as a whole, to distribute responsibilities and improve the efficiency of its functioning in the market. This explains the relevance of the research topic. The purpose of the study is to analyze approaches to assessing the effectiveness of integrated planning and determine the most appropriate. Objectives of the study: to analyze approaches to assessing the effectiveness (multifactorial, sectoral, integrated), to determine the approach used to evaluate the effectiveness in practice, and to determine the criterion of effectiveness as an integral indicator, the value of which can be judged on the extent to which the goals of the integrated plan are implemented. Since the efficiency of this mechanism is a multidimensional concept, it is usually impossible to obtain the efficiency criterion in the form of a scalar function. In this case, it is possible to use the multicomponent criterion obtained as a result of the study, the components of which are independent, relatively independent from each other by the criteria of micro, meso and macro efficiency.
\end{abstract}

Keywords: logistics, supply chain, supply chain management, integrated planning, planning efficiency.

\section{Introduction}

Nowadays, the necessity of rationale for long-term goals of business development and appliance of integrated planning is becoming more obvious. The process of market integration and globalization is increasingly turning economic subjects into network structures or macro logistics systems or supply chains.

A supply chain of a company includes geographically allocated objects where raw materials, finished commodity and material in process are bought, modified, stored or sold and products distribution channels connecting these objects. A company, suppliers, customers, third party representatives or other firms the company deals with can run these objects.

The purpose of the companies is an effective price rise of their products while they are being transferred along the supply chain in proper quantity and scope of supply, in due time and at a competitive price and transported to the geographically dislocated markets.

\section{Problem Statement}

Currently, there is a need to use a comprehensive or integrated planning of logistics activities, which will not only see the future prospects, but also to show the entire chain of the business process of the organization as a whole, to distribute responsibilities and improve the efficiency of its functioning in the market. And also to determine the integral indicator, the value of which can be judged on the extent to which the goals of the integrated plan are implemented.

\section{Research Questions}

A number of assumptions are made in this research and various research methods are used. The results obtained on the basis of these methods can come up for discussion. First, criteria for assessment of the aggregated indicators of efficiency of the integrated planning can be added. Secondly, it is possible to adapt this technique to the assessment of the integrated planning efficiency on various branch markets. 


\section{Purpose of the Study}

The purpose of the study is to analyze approaches to assessing the effectiveness of integrated planning. It also requires to determine criterion of effectiveness as an integral indicator, the value of which can be judged on the extent to which the goals of the integrated plan are implemented.

\section{Research Methods}

Delphi technique and econometric methods and models corresponding to the set objectives were used. Conceptual approaches to performance evaluation are stated in many scientific works. Modification of these approaches in the framework of supply network planning of manufacturing enterprises is successfully carried out in these works. Referring to these works, we offer a modified approach that is able to take into account specific features of the business enterprises on retail market connected with their dependence on competitive situation and consumers.

\section{Findings}

Supply chain management is the integration of the key business processes starting from the commercial user, covering all the suppliers of goods, services and information and adding consumer value [1].

The traditional aim of supply chain management consists in minimization of total logistical costs at the satisfaction of the fixed demand.

For the creation of effective planning at the enterprise there has to be a planning system, i.e. an ordered structure of separate types of planning. The main requirements to such a system are the following:

- documentation. It is important to document the basic parts of the plans to coordinate the planned calculations and the control of plans fulfillment;

- $\quad$ standardization. Drawing up documentation has to be fulfilled according to the existing standards;

- organization. The organizational mode which on the one hand would arrange activities of plan development, and on the other hand, would provide flexibility of the planning system, opportunities for improvisation and adaptation to the changing conditions;

- accuracy. It is necessary to reasonably determine the accuracy of measurement of characteristics of planning objects;

- coordination. All the private plans of the planning system have to be approved as between different planning levels (plans integration), and within the framework of one level (plans coordination). Besides, it is necessary to approve the purposes, forecasts, events, means, actions of responsible people, degree of necessity, urgency, hierarchy, sequence, flexibility, etc.;

- continuity, flexibility and cyclicality. The continuity resides in the fact that when the first plans are being developed and implemented, the development of the other starts. Some plans are being developed in parallel. The flexibility resides in the fact that likelihood of confusing conditions and plans review is taken into account. The cyclicality resides in the fact of systematic review, refining and adjustment considering changing circumstances, purposes, tasks, events of the same plans as approaching the time period of their implementation;

- completeness, i.e. scope of all the aspects of the enterprise activities, including logistics activities.

The integrated planning may be defined as the process of development and application of the unified crossfunctional corporate plan. The integrated planning can be defined as process of development and application of the unified cross-functional corporate plan.

High-level integrated planning demands consolidation of processes of scheduling and information about sales, advertising, clients, products, manufacture, purchases, supply chains and methods of product distribution, and even research and development into a unified plan from the point of view of financing and implementation within the framework of the whole corporation.

The need for the integrated planning can be seen in activity of large organizations. The scale and fields of such companies' activity demand their separation into several groups according to their functions, regions, business units and so on. At the same time each group is responsible for the management of the part of business assigned to it.

To achieve the set goals and overall performance effectively each group must plan and organize its activity and distribute the available resources correctly. Nevertheless, such a situation encourages the state when business line development and the activities of functional divisions are conceptually divided while the actions and plans of different groups are often absolutely disconnected.

The benefits of the integrated planning are the following:

- improvement of planning processes and implementation of integrated planning may have an essential influence on financial and operational activity of the company;

- improvement of operating activity and customer service;

- clear responsibility and accountability improves coordination and builds processes and the sequence of functions fulfillment; 
- information in a whole and the level of its separate detailing is being built in accordance with a corporate model of planning;

- $\quad$ processes and tools help to support effective and well-timed data collection and information analysis and also they help to prepare reports [2].

Thus, integrated planning of logistics at the enterprises in general increases efficiency of resources distribution, management decisions and the actual job processing.

Integrated planning is based on so-called concept of "Sales and Operations Planning, S\&OP", but this process is connected not only with planning of sales volume and operating activities. Business and finance planning are quite important components of integrated planning (see fig. 1).

Such borders expansion guarantees control and coordination of all accepted assumptions, wanted levels of efficiency and daily tasks of sales and transactions, their compliance to business plans and to the expected financial performance. With such an approach discrepancy and possible plans variations can be seen at once, but not at the end of the accounting period. To implement integrated planning it is required to define indicators for efficiency evaluation of this process.

P. Drucker claimed that "it is easier to manage what can be measured". Therefore there is a necessity of development of assessment techniques of integrated planning efficiency for the enterprise. This technique should represent an algorithmic approach considering industry-specific features and a competitive situation [3].

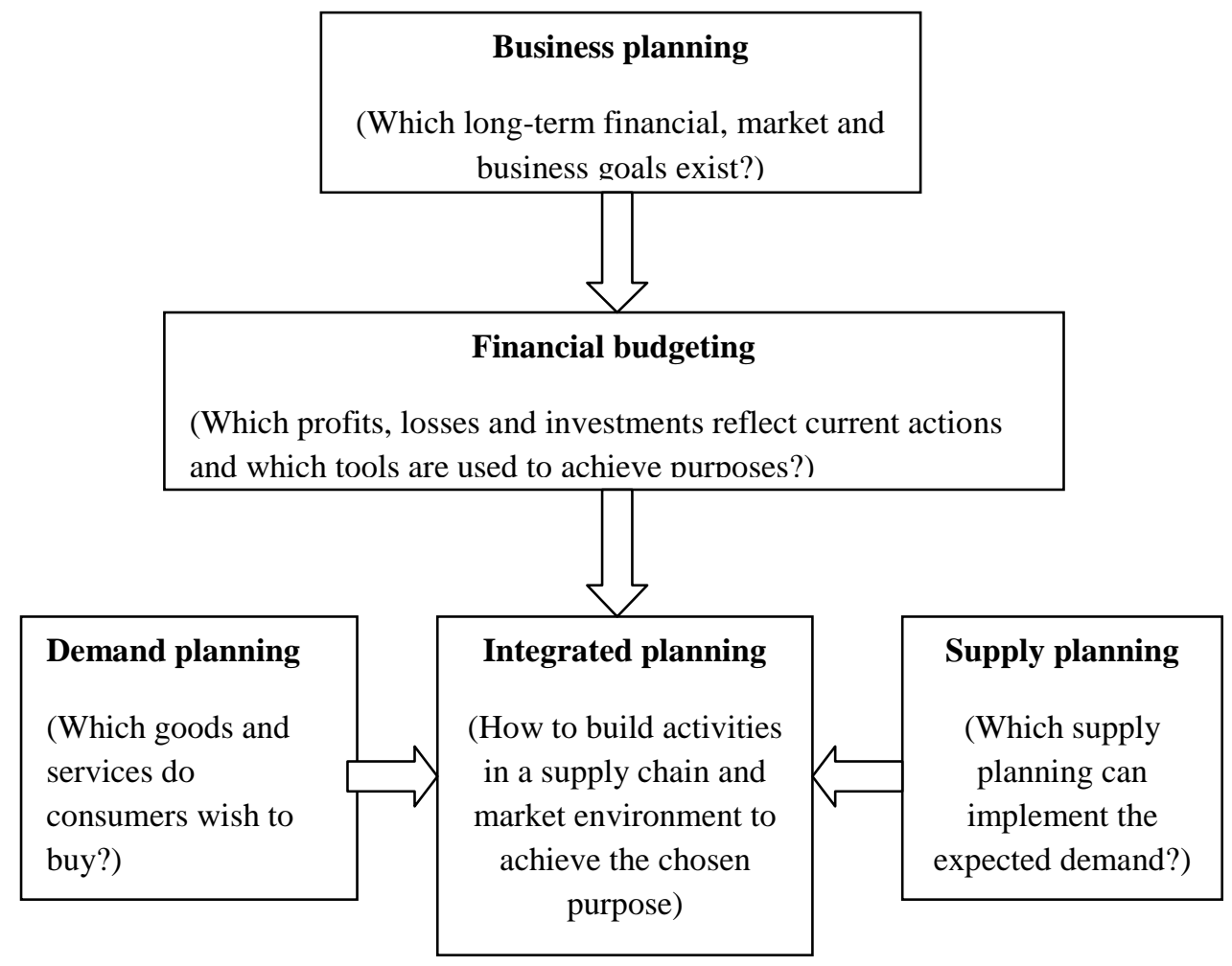

Figure 1. The place of integrated planning in general planning system of the organization (Source: compiled by the authors)

With a variety of (multifactorial, industry, complex) approaches to efficiency evaluation, criterion approach is often used in practice. Criterion approach is understood as an (integral as a rule) indicator according to the size of which it is possible to evaluate the degree of compliance of the estimated alternative to the stated purposes.

In this case the task is to choose such criteria on the basis of which analysis it is possible to estimate efficiency components: economic feasibility, productivity and efficiency of the integrated planning of an organization. The chosen criteria must meet a number of the requirements, such as reliability, objectiveness, validity, consistency, comparativeness, completeness, acceptability.

Generally the efficiency can be presented as function of resources, results and parameters of the external environment defining the market condition:

$$
E=F(\mathrm{x}, \mathrm{y}, \mathrm{a})
$$

where $\mathrm{E}$ is an efficiency indicator of planning mechanism of trade channels' marketing; $x$ is a vector of resources (subsystems) needed for the implementation of the mechanism; $y$ is a vector of planned (or achieved) results, $a$ is a vector of parameters of external environment; the change of these parameters leads to efficiency variation [4].

Summarizing the works of different authors, it is possible to give the following recommendations about the development of the system of efficiency evaluation of the integrated planning for the market of retail sales. Firstly, insignificant quantity of criteria (necessary sufficiency) which are able to provide interrelation between the purposes, 
resources, technologies must be claimed and balanced according to all considered aspects. Secondly, compulsory condition is the capability of the information systems operating at the enterprise to provide timely, exact, reliable information. Thirdly, the organizational control facilities existing at the enterprise must provide a possibility of efficiency monitoring with the set frequency.

Let us emphasize the advantages of the offered system of requirements. The adequate choice of indicators will promote achievement of the goals of an enterprise due to coordination and agreement. As the efficiency of this mechanism is a complex concept it is not possible, as a rule, to receive criterion of efficiency in the form of the scalar function. In this case the use of multicomponent criterion, the elements of which are independent criteria, is possible. In this case the use of multicomponent criterion, the elements of which are independent criteria, is possible [5].

By internal efficiency we mean the optimal degree of the use of internal resources, opportunities and enterprise competences.

By external efficiency one should understand expediency and rationality of the use of enterprise external opportunities connected with its environment - micro (consumers, competitors, suppliers, partners) and macro (legislative and executive authority). The two given types create a concept of overall effectiveness which is offered by P. Drucker [3].

We suggest making an assessment of the complex indicator of efficiency based on three integral indicators: external (macro), internal (micro) and mesoefficiency to assess the efficiency of the integrated planning of the enterprise in the retail market. What is more, the indicator of mesoefficiency will consider financial risks of business processes planning. The offered indicators are viewed from the perspective of profitability, efficiency and effectiveness. At the same time the complex indicator of the integrated planning may be assessed both at a mechanism development stage - to determine planned efficiency, and in the course of implementation - to monitor current efficiency.

The scheme of indicators formation at the assessment of the integrated planning efficiency of the enterprise is represented in table 1 .

Table 1. The system of indicators at the assessment of the integrated planning efficiency

\begin{tabular}{|c|c|c|c|c|}
\hline & $\begin{array}{l}\text { Assessment of } \\
\text { economic } \\
\text { feasibility }\end{array}$ & $\begin{array}{l}\text { Assessment of } \\
\text { productivity }\end{array}$ & $\begin{array}{l}\text { Assessment of } \\
\text { performance }\end{array}$ & \\
\hline $\begin{array}{l}\text { Internal (micro) } \\
\text { efficiency }\end{array}$ & $\begin{array}{l}\text { Coverage of a } \\
\text { sale subsystem } \\
\text { - Level of balance } \\
\text { of a purchase and } \\
\text { delivery } \\
\text { subsystem }\end{array}$ & $\begin{array}{l}\text { - Level of } \\
\text { regularity } \\
\text { purchases } \\
\text { - level of } \\
\text { motivation }\end{array}$ & $\begin{array}{l}\text { Fulfillment of } \\
\text { purchase } \\
\text { standards of a } \\
\text { sale subsystem } \\
\text { - Costs of the } \\
\text { arrangement of a } \\
\text { purchase } \\
\text { subsystem }\end{array}$ & $\begin{array}{l}\text { Integral } \\
\text { indicator of } \\
\text { internal } \\
\text { efficiency }\end{array}$ \\
\hline $\begin{array}{l}\text { External (macro) } \\
\text { efficiency }\end{array}$ & $\begin{array}{ll}\text {-Level } & \text { of } \\
\text { management } & \\
\text { flexibility } & \\
\text {-Level } & \text { of } \\
\text { personnel } & \\
\text { competence } & \end{array}$ & $\begin{array}{ll}\text {-Level } & \text { of } \\
\text { innovation } & \\
\text {-Level } & \text { of } \\
\text { cooperation } & \end{array}$ & $\begin{array}{ll}\text {-Level } & \text { of } \\
\text { competitive } & \\
\text { performance } & \\
\text {-Level } & \text { of } \\
\text { development } & \\
\text { ability } & \end{array}$ & $\begin{array}{l}\text { Integral } \\
\text { indicator of } \\
\text { external } \\
\text { efficiency }\end{array}$ \\
\hline $\begin{array}{l}\text { Financial risks } \\
\text { (mesoefficiency) }\end{array}$ & $\begin{array}{l}\text { Financial risks } \\
\text { due to low level } \\
\text { of economic } \\
\text { feasibility }\end{array}$ & $\begin{array}{l}\text { Financial risks } \\
\text { due to low level } \\
\text { of productivity }\end{array}$ & $\begin{array}{l}\text { Financial risks } \\
\text { due to low level } \\
\text { of effectiveness }\end{array}$ & $\begin{array}{l}\text { Integral } \\
\text { indicator of } \\
\text { mesoefficiency }\end{array}$ \\
\hline
\end{tabular}

Source: compiled by the authors.

Information for calculation of the aggregated indicator of internal efficiency of the integrated planning of the enterprise is represented in table 2 .

For the assessment of external efficiency of the integrated planning mechanism of an enterprise on the retail market we will use the following criteria: flexibility of management, competence of personnel, innovation, level of cooperation and competitiveness, development ability (see table 3). Each of the criteria is estimated according to 100-mark scale by the method of the displaced ideal that assumes the assessment of the real subsystem in comparison with the ideal one (100 points). 
Table 2. The system of criteria for calculation of the aggregated indicator of internal efficiency of the integrated planning

\begin{tabular}{|l|l|c|}
\hline Criterion name & Indication & Value \\
\hline 1. Coverage of sales subsystem & $\mathrm{Ri}^{2}$ & from 1 to 6 \\
\hline $\begin{array}{l}\text { 2. Level of balance of purchase and supply subsystem } \\
\text { 3. Level of steady purchase }\end{array}$ & $\mathrm{R} 2^{2}$ & from 1 to 6 \\
\hline 4. Level of sales motivation & $\mathrm{R} 3^{3}$ & from 1 to 6 \\
\hline 5. Efficiency of sales subsystem & $\mathrm{R} 4^{3}$ & from 1 to 6 \\
\hline $\begin{array}{l}\text { 6. Costs of management of purchase subsystem } \\
\text { Notations: } \mathrm{R}^{\mathrm{j}} \mathrm{j}-\text { upper index, corresponding to the number of assessment level }(1-\text { economic } \\
\text { feasibility assessment; } 2-\text { productivity assessment; } 3-\mathrm{effectiveness} \text { assessment; } \mathrm{i}-\text { ordinal }\end{array}$ \\
\hline
\end{tabular}

Source: compiled by the authors.

Table 3. The criteria system for calculation of the aggregated indicator of external efficiency of the integrated planning

\begin{tabular}{|l|c|c|}
\hline Criterion name & Indication & Value \\
\hline 1. Level of management flexibility & $\mathrm{S} 1^{1}$ & from 1 to 6 \\
\hline 2. Level of personnel competence & $\mathrm{S} 2^{3}$ & from 1 to 6 \\
\hline 3. Level of innovation & $\mathrm{S} 3^{1}$ & from 1 to 6 \\
\hline 4. Level of cooperation & $\mathrm{S} 4^{2}$ & from 1 to 6 \\
\hline 5. Level of competitiveness & $\mathrm{S} 5^{3}$ & from 1 to 6 \\
\hline 6. Level of development ability & $\mathrm{S} 6^{2}$ & from 1 to 6 \\
\hline
\end{tabular}

Source: compiled by the authors.

The available aggregated indicators allow creating two integrated indicators of efficiency and also an integrated indicator of financial risk or mesoefficiency. The obtained complex efficiency indicator of the integrated planning of an enterprise on the retail market can be interpreted in the following way: value of the integrated indicator in the range [033] correspond to low value of efficiency, [33-66] correspond to the average value, [66 - 100] - to high value of efficiency. The similar gradation is applicable for interpretation of risk.

Results of efficiency assessment of the integrated planning on the retail market are represented in table 4 . The highest level of assessment is received in the course of the research made at the retail chain "Magnit", JSC "Tander". Analyzing results it is possible to draw a conclusion that the value of the integrated indicator $\mathrm{E}=74,75$ can be surely classified as "the high level" of efficiency, nevertheless, there is a sufficient potential for its increase. Integrated assessment of financial risk or mesoefficiency (Risk=25,25) shows that, in total, the risk connected with inefficiency of integrated planning is low, but negative tendencies from the side of external efficiency can lead it into the zone of midlevel risk.

Table 4. Results of assessment of efficiency indicators of the integrated planning on the retail market of the studied enterprises

\begin{tabular}{|l|c|c|c|c|}
\hline \multicolumn{1}{|c|}{ Enterprise } & $\begin{array}{l}\text { "Magnit" } \\
\text { JSC "Tander" } \\
\text { Retail chain }\end{array}$ & $\begin{array}{c}\text { Auchan } \\
\text { Retail Russia }\end{array}$ & $\begin{array}{c}\text { "Pyaterochka" } \\
\text { Federal retail } \\
\text { chain }\end{array}$ & $\begin{array}{c}\text { "Karusel"” } \\
\text { Hypermarkets }\end{array}$ \\
\hline $\begin{array}{l}\text { Aggregated indicator of } \\
\text { internal efficiency }\end{array}$ & 62,2 & 71,0 & 56,3 & 54,2 \\
\hline $\begin{array}{l}\text { Aggregated indicator of } \\
\text { external efficiency }\end{array}$ & 87,3 & 64,7 & 52,7 & 46,9 \\
\hline $\begin{array}{l}\text { Integrated indicator of } \\
\text { efficiency }\end{array}$ & 74,75 & 67,85 & 54,5 & 50,55 \\
\hline $\begin{array}{l}\text { Integrated assessment of } \\
\text { financial } \\
\text { (mesoefficiency) risk }\end{array}$ & 25,25 & 32,15 & 45,5 & 49,45 \\
\hline
\end{tabular}

Source: compiled by the authors. 


\section{Conclusion}

In large, it is possible to claim that one of the significant factors encouraging an increase in competitiveness of the retail enterprises is the improvement of the methodical support applied in the integrated planning.

Thus, the integrated planning of logistics activities allows not only to define its future prospects, but also to show a chain of business process of the organization in general, to distribute duties and to increase efficiency of its functioning in the market.

\section{References}

1. A.I. Drozhzhin, Logistics. Moscow: Marketing (2008). [in Rus.].

2. T.V. Aleksinskaya, Fundamentals of logistics. Taganrog: Publishing house TRTU (2005). [in Rus.].

3. P. Drucker, Management: Tasks, Responsibilities, Practices. New York: Harper\&Row (1973).

4. D.J. Bowersox, D.J. Closs, Logistical management: the integrated supply chain - the science of management of material and information flows. Moscow: JSC "Olympus-Business" (2003). [in Rus.].

5. G. Pokaraev, A.Ellaryan, Risk of integrated business processes in the corporate sector of the national economy. RISK: Resources, Information, Supply, Competition, 4, 10-13 (2009). [in Rus.]. 